\title{
Subject
}

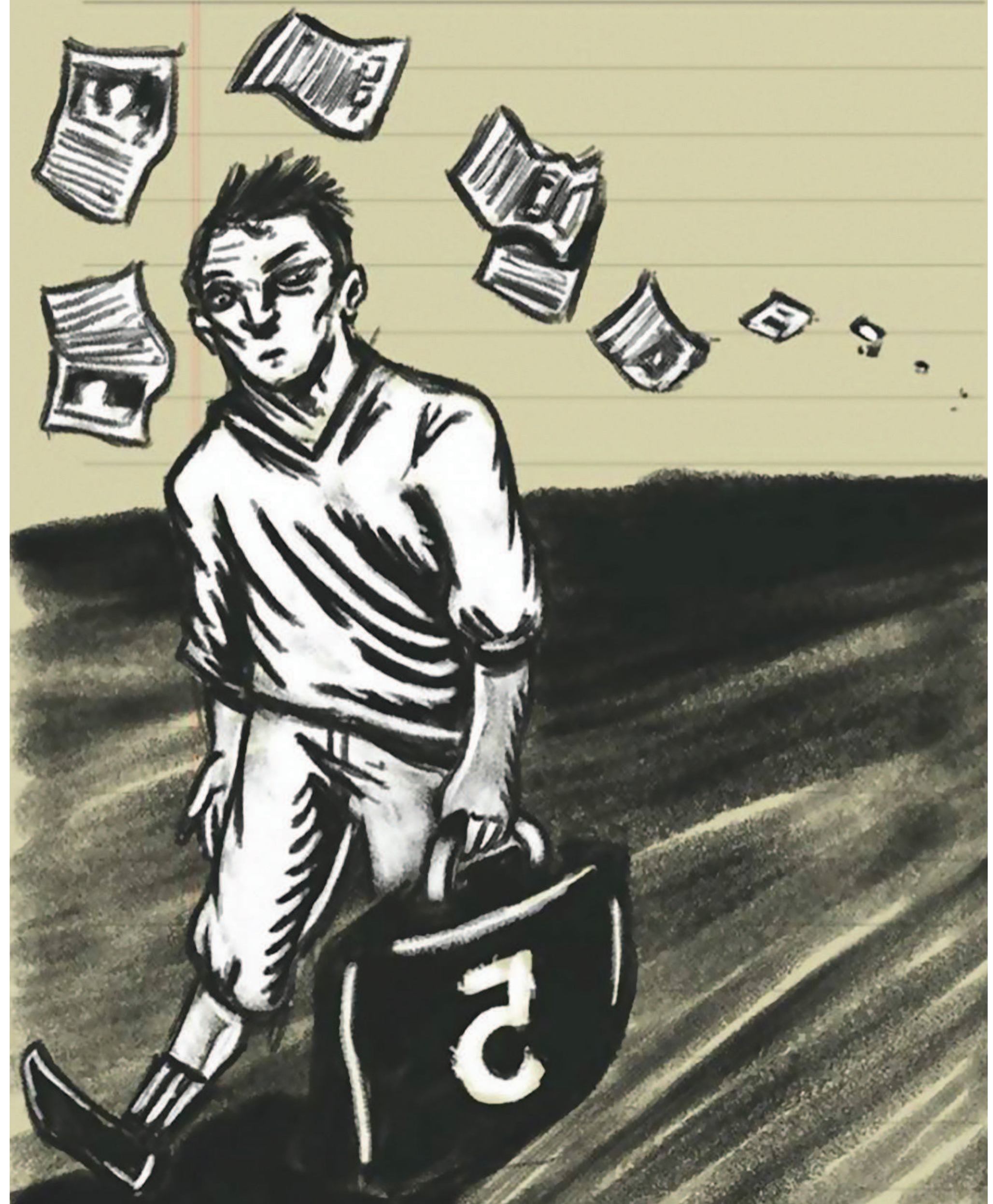



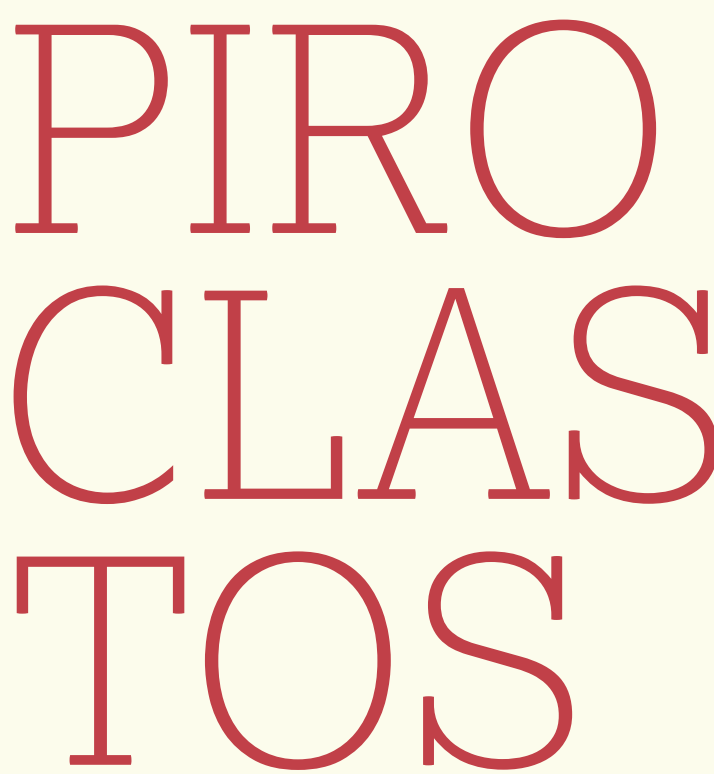

Do grego piro + klastós, -é, -ón.

Fragmentos de fogo expelidos durante a erupção e que solidificam. 


\section{INÉDITO E 3 \\ DE TREME AINDA}

- FABIO WEINTRAUB

\section{CAVE DE CHAUVET}

uma avalanche fechara

a entrada principal:

cápsula de tempo

para bárbaros futuros

sobre a pedra há trinta mil anos

os traços parecem frescos

e a boca aberta dos cavalos

ainda emite relinchos

como os cornos dos bisontes

ainda se chocam

e as patas multiplicadas dos felinos

projetam o protocinema

de corridas e saltos

no encalço da presa

que também somos nós

sem torso a vênus,

única figura humana,

em conúbio com o touro

(como em picasso)

destila a treva primeva

na lousa anônima

(hieróglifo, espelho)

a impressão de uma palma

assinatura remota

do extinto artista

à nossa espera 


\section{MASTER CHEF}

hipocondria absoluta:

a hipocondria tem de tornar-se uma arte

ou uma pedagogia

novalis

eu achava sangue

uma coisa fascinante

estava marcada

minha última operação

para a troca do quadril

queria levá-lo pra casa

em vez de abastecer

o banco de ossos do hospital

torrei o saco do cirurgião

ameacei mudar de médico

quem não chora não mama

quando acordei

a primeira coisa que vi

foi minha bisteca

e um bilhete de boa sorte

a carne soltou na fervura

provei um pedaço

joguei sal, alho, pimenta

abri uma taça de vinho

mandei ver

antropófago, não

só mastigo o que é meu

me considero mais

um gourmet da dor 


\author{
SOZINHO \\ existem tatuadores \\ especializados em paraplégicos \\ quando não se sente dor \\ desenhar é bem mais fácil \\ maior a margem de improviso \\ há também os que preferem \\ criar sobre cicatrizes \\ injeto sangue na cena artística \\ minha própria pele \\ cobri quase totalmente \\ quando eu morrer \\ quero que me empalhem \\ vermes fazem land art \\ eu trabalho sozinho
}




\section{SIMPATIA}

se antes de se deitar

debaixo do travesseiro

você esconde uma rosa

seu sonho se realiza

o pesadelo também

mas a rosa logo murcha

e na fronha o fio de baba

escurece totalmente

o pesadelo também

mas nos espinhos do caule

(a rosa é vermelha)

você espeta algum dedo

e perde a ereção de vez

o pesadelo também

mas seu reflexo se alonga

no lago supergelado

onde batizam as crianças

melhor dormir sobre a pedra

sem rosa nem pesadelo

no travesseiro de pedra

com uma placa entre os dentes

proteção contra bruxismo

FABIO WEINTRAUB (São Paulo, 1967). Doutor em Teoria Literária e Literatura Comparada pela USP. Publicou os livros de poemas Sistema de erros (1996), vencedor do prêmio Nascente em 1994; Novo endereço (2002), que recebeu os prêmios Cidade de Juiz de Fora, em 2001, e Casa de las Américas, em 2003; Baque (2007) e Treme ainda (2015). 